\title{
Penggunan Sevima Edlink Sebagai Media Pembelajaran Online untuk Mengajar dan Belajar Bahasa Indonesia
}

\author{
Andi Wibowo ${ }^{1}$ \\ Indah Rahmayanti ${ }^{2 *}$ \\ ${ }^{1}$ MTs PKP Jakarta Islamic School, \\ Jakarta Timur, DKI Jakarta, \\ Indonesia \\ ${ }^{2}$ Universitas Muhammadiyah Prof. \\ DR. Hamka, Jakarta Timur, DKI \\ Jakarta, Indonesia \\ *email: \\ indahrahmayanti@uhamka.ac.id
}

Received: 3 Februari 2020

Accepted: 24 Maret 2020

Published: 26 Maret 2020

doi:

http://dx.doi.org/10.29405/imj.v2i2 67

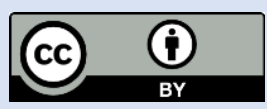

(C) 2020 Oleh authors. Lisensi Imajeri: Jurnal Pendidikan Bahasa dan Sastra Indonesia, Uhamka, Jakarta. Artikel ini bersifat open access yang didistribusikan di bawah syarat dan ketentuan Creative Commons Attribution (CC-BY) license. (http://creativecommons.org/licens es/by/4.0/).

\begin{abstract}
Abstrak
Penelitian ini bertujuan untuk melihat dan menelaah dari penggunaan Sevima Edlink sebagai media pembelajaran online untuk mengajar dan belajar bahasa Indonesia. Hasil evaluasi untuk media Sevima Edlink ditelaah dengan menggunakan teori Sections dan Chaple, bahwa media Sevima Edlink ini sangat direkomendasikan untuk dijadikan sebuah media pembelajaran elektronik pada pembelajaran bahasa Indonesia, karena memiliki fitur-fitur yang mendukung pada kebutuhan-kebutuhan pembelajaran bahasa Indonesia. Media Sevima Edlink ini selain bisa memberikan materi, media tersebut juga bisa berinteraksi dengan jarak jauh melalui sebuah diskusi percakapan via tertulis maupun video. Media ini diharapkan terus dipromosikan di satuan pendidikan yang terendah hingga yang tertinggi agar akademisi maupun pelajar bisa mengetahui adanya keberadaan media Sevima Edlink ini. Saran dari peneliti adalah untuk fitur yang sudah ada sementara bisa ditingkatkan lagi agar pembelajaran jarak jauh semakin nyaman dan media ini lebih baik bisa digunakan digunakan dari tingkat satuan pendidikan yang terendah tanpa ada kategori media yang sering digunakan oleh perguruan tinggi.
\end{abstract}

Kata kunci: Teknologi; E-Learning; Sevima Edlink; Bahasa Indonesia

\begin{abstract}
This study aims to see and examine the use of Sevima Edlink as an online learning medium for teaching and learning Indonesian. The evaluation results for Sevima Edlink's media are examined using Sections and Chaple's theory, that Sevima Edlink's media is highly recommended as an electronic learning media for Indonesian language learning, because it has features that support the needs of Indonesian language learning. Apart from being able to provide material, Sevima Edlink's media can also interact remotely through a conversation discussion via written or video. It is hoped that this media will continue to be promoted in the most trusted tertiary education units so that academics and students can find out about the existence of this Sevima Edlink media. Suggestions from researchers are for existing features that can be temporarily improved so that distance learning becomes more comfortable and this media can better be used from the lowest education unit level without any media categories that are often used by universities.
\end{abstract}

Keywords: Technology; E-Learning; Sevima Edlink; Indonesian Language

\section{PENDAHULUAN}

Teknologi Komunikasi dan informasi bisa dikatakan sebagai tempat ataupun wadah untuk memberikan sebuah informasi untuk jarak jauh. Teknologi selalu berinovasi tiap tahun ke tahun bahkan di era revolusi industri 4.0 yang berbasis teknologi, dengan adanya itu kegiatan belajar mengajar kini sudah tidak lagi harus berada di dalam kelas. Industri 4.0 pertama kali diciptakan di negara Jerman pada tahun 2011 yang memfokuskan pada industri digital. Industri 4.0 ini menggabungkan sebuah teknologi dan digital saat itu dan kini industri berkembang sangat pesat. (Satya, 2018) Revolusi industri 4.0 ditandai dengan beberapa 
kemunculan industri diantaranya teknologi baru untuk sains, kecerdasan buatan, robotik, cloud, cetak tiga dimensi, dan teknologi nano. (Ghufron, 2018) Landasan yang mendasari adanya revolusi industri 4.0 yaitu adanya perkembangan komputer elektronik digital atau komputer pribadi yang penggunaan mikroprosesor yang terus meningkat, oleh karena itu apabila Indonesia ingin bersaing di revolusi insdustri 4.0 maka kemampuan harus ditingkatkan. . (Syamsuar \& Reflianto .2018) Pengajar ataupun pendidik bisa memberikan sebuah materi kepada siswa melalui jarak jauh dengan perantara aplikasi pembelajaran online dan siswa bisa mendapatkan materi dengan jarak jauh. Inovasi teknologi di era revolusi industri 4.0 banyak aplikasi pembelajaran online yang beredar di internet yang mudah diakses gratis ataupun yang berbayar. Aplikasi Sevima Edlink ini memiliki fitur-fitur yang direkomendasikan untuk tingkat Universitas, namun apabila guru mengaplikasikan aplikasi ini di tingkat sekolah, guru bisa memanfaatkan dengan cara mensosialisasikan kepada siswa tentang penggunaan aplikasi ini, setelah guru mensosialisasikan tentang aplikasi ini, guru akan mendampingi siswa untuk memanfaatkan fitur-fitur yang ada di Sevima Edlink dalam pembelajaran. Pengguna perangkat pembelajaran online pun harus bisa memilih aplikasi pembelajaran online yang bisa membantu mempermudah penggunanya.

Media pembelajaran online yang beredar yaitu Google Classroom, Sevima Edlink, Quipper, Kelas Pintar, KelasKita, Ruang Guru, Rumah Belajar, Kahoot,Class Dojo, Edmodo, dan masih banyak yang lainnya. Peran dari media ini untuk membantu guru atau pengajar apabila mereka berhalangan hadir ataupun ada tugas dinas yang mengakibatkan mereka tidak masuk ke dalam kelas, mereka bisa memberikan materi ataupun postes dari jarak jauh dan mereka juga bisa memantau hasil pengerjaan siswa. Banyaknya media pembelajaran online yang beredar harus disesuaikan dengan kebutuhan yang dibutuhkan oleh pengguna media pembelajaran online, agar pengguna bisa mengeksplorasi kegiatan belajar mengajar melalui jarak jauh. Dengan menggunakan media pembelajaran online diharapkan efisiensi waktu untuk pembelajaran jarak jauh lebih baik lagi. Peneliti kali ini ingin mengevaluasi media pembelajaran online yang jarang terdengar untuk dimanfaatkan dalam kegiatan pembelajaran online. Media yang akan dievaluasi yaitu media pembelajaran online Sevima Edlink, diantara media-media yang digunakan pembelajaran online, media ini yang jarang terdengar untuk digunakan dalam kegiatan pembelajaran online, dalam arti mempromosikan media tersebut di media sosial, tetapi media pembelajaran online ini biasa digunakan oleh perguruan tinggi universitas khususunya dosen untuk memberikan pembelajaran materi kepada mahasiswa dengan jarak jauh.

Penelitian ini ingin mengevaluasi media tersebut untuk kegiatan pembelajaran bahasa indonesia berbasis online di tingkat SMP dan SMA. Apakah media pembelajaran online Sevima Edlink bisa mengakomodasi untuk pembelajaran bahasa Indonesia khususnya pada pembelajaran jarak jauh. Selain itu peneliti ingin melihat fitur-fitur dan pemakaian dasar yang ada pada aplikasi Sevima Edlink untuk pembelajaran bahasa khususnya bahasa Indonesia, Peneliti akan menggunakan prinsip Sections dan teori dari Chapple pada media pembelajaran online Sevima Edlink ini. Berikut adalah ulasan dan evaluasi tentang media pembelajaran online Sevima Edlink.

Sebelum masuk ke bagian media Sevima Edlink, terlebih dahulu akan dijelaskan tentang teknologi. Seperti yang sudah diketahui bahwa teknologi dibagi menjadi dua bagian yaitu teknologi informasi dan teknologi komunikasi, perbedaannya adalah untuk teknologiinformasi lebih memfokuskan sebagai alat bantu atau pengelolaan sebuah informasi, dan untuk teknologi komunikasi lebih memfokuskan pada mentransfer sebuah data dari perangkat satu ke perangkat yang lainnya. Peranan sebuah teknologi informasi dan komunikasi mempunyai peranan besar di tengah-tengah kehidupan masyarakat sekarang, khususnya untuk mengetahui sebuah informasi secara cepat dan aktual. Pada dunia 
pendidikan dari tingkat dasar sampai perguruan tinggi pasti menggunakan sebuah teknologi informasi dan komunikasi pada kegiatan akademiknya dan administrasinya. Sebuah teknologi informasi dan komunikasi bisa menguntungkan banyak masyarakat keseluruhan.(Widarma, 2019) Selain itu teknologi komunikasi memberikan sebuah kemudahan untuk bisa berkomunikasi individu dengan individu yang lainnya dengan jarak jauh dengan memanfaatkan sebuah teknologi.(Harun \& Fauzan, 2019) Ketika sebuah teknologi komunikasi sudah canggih dan maju, maka kompetensi seorang guru harus juga ikut dikembangkan dari segi penggunaan teknologi komunikasi untuk kepentingan sebuah pembelajaran online atau e-learning. Undang-undang nomor 14 Tahun 2005 juga menjelaskan bahwa meningkatkan sebuah kompetensi seorang guru dengan ilmu dan teknologi sangat penting karena ilmu dan teknologi akan berkembang dengan pesat.(Andi\&dkk,2020) Sebuah penggunaan teknologi informasi dan komunikasi selalu berkembang dari tahun ke tahun mulai dari bentuk strategi maupun polanya yang pada dasarnya dirangkum di sistem $e$ learning.(Prabandari,2019) Apabila kompetensi seorang guru terus dikembangkan dan mengikuti perkembangan teknologi informasi dan komunikasi maka ada harapan pembaharuan strategi dan merancang media pembelajaran yang membuat siswa terus termotivasi untuk belajar. (Miftah \& dkk,2019) Sebuah program pembelajaran interaktif berbasis komputer teknologi informasi dan komunikasi memiliki nilai lebih saat diterapkan pada pengajaran karena karena mampun memberikan keaktifan belajar siswa yang tinggi. (Amanullah 2020) Pada penjelasan di atas bisa disimpulkan bahwa teknologi khususnya teknologi informasi dan komunikasi berdampak besar pada kehidupan masyarakat bahkan di dunia pendidikan.

Cikal bakal sebuah e-learning berasal dari teknologi informasi dan komunikasi. Ketika sebuah teknologi informasi dan komunikasi berinovasi, maka terbuatlah sebuah aplikasi e-learning yang sekarang banyak digunakan oleh dunia pendidikan khususnya di dalam proses akademik. E-learning dalam bahasa Indonesia yaitu pembelajaran elektronik adalah sebuah bentuk pembelajaran yang lebih menggunakan media untuk mengajar memanfaatkan sebuah teknologi elektronik yang bersifat mobile ataupun nonmobile. Maksudnya adalah pembelajaran elektronik ini bisa dilakukan di mana saja dengan sistem jarak jauh. Perbedaan mobile learning dengan nonlearning adalah untuk mobile learning lebih memfokuskan pada pembelajaran di mana saja dan kapan saja, kalau pembelajaran nonlearning tidak bisa dilakukan dengan sistem jarak jauh. (Eliando,2019) Pembelajaran elekronik juga membutuh beberapa komponen yang mendukung untuk pembelajaran elektronik. Komponen yang mendukung adalah $L A N$, WAN, dan internet. Komponen tersebut harus ada pada pembelajaran elektronik karena komponen tersebut menjadi landasan pembelajaran elektornik tersebut berjalan dengan lancar. (Supriadi \& Widyastuti, 2019) Ada beberapa model dimensi untuk pembelajaran e-learning yaitu dimensi yang pertama adalah sebuah pembelajaran e-learning harus mempunyai konten yang berkualitas, pengiriman, layanan, dan struktural yang bagus dan unggul sebagai standar kualitas. Dimensi yang kedua harus mempertimbangkan motivas belajar, fasilitator pembelajaran, dan lingkungan belajar yang kolaboratif agar siswa nyaman untuk melakukan e-learning. Dimensi yang ketiga yaitu hasil belajar siswa. Siswa harus dipastikan mendapatkan hasil belajar yang sesuai dengan kemampuan siswa tersebut. Pembelajaran e-learning ini memerlukan biaya yang murah. Dimensi yang keempat yaitu evaluasi program yang berlangsung dan dimensi yang kelima yaitu adaptasi dan peningkatan yang berkelanjutan. (Al-fraihat, Joy, \& Sinclair, 2020) Sistem pembelajaran e-learning ini memiliki beberapa manfaat yaitu (1) Fleksibilitas tempat dan waktu, pembelajaran e-learning tidak selalu siswa hadir di dalam kelas, tetapi siswa bisa mengakses pembelajaran e-learning di temapat di mana saja dan waktunya tidak ditentukan. (2) Independent learning, sistem pembelajaran e-learning ini memberikan leluasa dari siswa 
sendiri untuk mengendalikan hasil belajara yang mereka lakukan. Mereka akan menentukan kapan untuk memulai pembelajaran e-learning dan kapan untuk menyelesaikan tugas yang diberikan. (3) Biaya, Pembelajaran e-learning ini sangat rendah untuk menggunakan biaya, biaya yang dimaksudkan adalah tidak perlu adanya biaya trasportasi, biaya administrasi, ataupun biaya yang lainnya. (4) Fleksibilitas kecepatan belajar e-learning, Pembelajaran ini untuk membantu siswa memahami materi yang diberikan oleh guru ataupun pengajar apabila siswa tidak paham, maka siswa bisa mengulanginya dengan sendiri sampai siswa memahaminya. (5) Standarisasi pengajaran. Sistem yang digunaka oleh e-learning akan sama dan tidak akan berubah dengan kondisi hati siswa. (6) Efektifitas pengajaran, pembelajaran elearning ini bisa memberikan sebuah simulasi ataupun kasus-kasus dengan memanfaatkan sebuah teknologi dan animasi untuk menunjang pembelajaran. (7) Kecepatan distribusi, sistem e-learning dapat menjaukan seluruh penjuru tempat, pengguna e-learning hanya tinggal mempersiapkan bahan ajar dan mengunduh media e-learningnya. (8) Ketersedian OnDemand, sistem e-learning dapat diakses kapan saja. (9) Otomatis proses administrasi, sistem e-learning menggunakan sistema Learning System Management (LSM). (Mulyati\&Priatna, 2020) Selain penjelasan di atas e-learning mempunyai sebuah karakteristik diantaranya yaitu Pertama, sebuah e-learning memanfaatkan sebuah teknologi yang terus berkembang. Kedua, sistem e-learning memanfaatkan keunggulan sebuah komputer diantaranya digital media dan jaringan komputer. Ketiga, menggunakan sistem bahan ajar yang bersifat mandiri, dan Keempat, memanfaatkan jadwal yang sudah tersedia dalam fitur media e-learning. (Yazdi, Matematika, \& Tadulako, 2012) Penjelasan di atas bisa disimpulkan bahwa e-learning atau pembelajaran elektronik sebuah pembelajaran yang menggunakan sistem jarak jauh tanpa terhalang oleh jaran dan waktu lalu pembelajaran elektronik tersebut harus didukung oleh beberapa komponen.

Perbedaan artikel penelitian ini dengan penelitian sebelumnya yaitu lebih memfokuskan pada kegunaan dan manfaat fitur-fitur media pembelajaran Sevima Edlink untuk kegiatan belajar dan pengajaran bahasa Indonesia di tingkat sekolah maupun Universitas. Penelitian sebelumnya dari artikel Penggunaan E-Learning dalam Pembelajaran Bahasa Indonesia di SMA Negeri Bali Mandara yang ditulis oleh I Putu Darmika \& dkk pada tahun 2018 menyatakan bahwa penggunaan media e-learning untuk pelajaran bahasa Indonesia ada beberapa temuan yaitu (1) mempermudah guru dalam mengajar, (2) penggunaan e-learning di sekolah khususnya di kelas memiliki respon yaitu sangat positif $(31,45 \%)$ dengan rincian terdapat $21(47,72 \%)$ memberikan resposn sangat setuju dan 23 $(52,27 \%)$ memberikan respons setuju. Penelitian di atas juga didukung oleh artikel Pemanfaatan Kelas Virtual Sevima Edlink untuk Memotivasi Mahasiswa Pendidikan Matematika Semester 1 Matakuliah Aljabar\&Trigonometri ditulis oleh Carolin Dwija Novandini dan Margaretha D.W Luta pada tahun 2018 dari Universitas Sanata Dharma Yogyakarta menyatakan bahwa pembelajaran matakuliah aljabar dan trigonometri berjalan dengan semestinya walaupun dibantu oleh media Whattsapp untuk mengolah data tetapi mahasiswa antusias untuk menggunakan Sevima Edlink untuk kegiatan pembelajaran virtual. Kedua Penelitian di atas juga didukung oleh artikel Meningkatkan Kedisiplinan Melalui Google Classroom dalam Mata Kuliah Bahasa Indonesia ditulis Lilisa Amaliah Rosdiana\&dkk tahun 2020 dari IKIP Siliwangi menyatakan bahwa pengumpulan tugas ke-1 dari total 36 mahasiswa hanya 21 mahasiswa yang berhasil mengumpulkan tugas tepat waktu. Tugas ke-2 lebih banyak lebih banyak yang mengumpulkan tugas tepat waktu yaitu 30 mahasiswa dari total 36 mahasiswa. Tugas ke-3 semua mahasiswa mengumpulkan tepat waktu. Jadi, Google Classroom ini terbukti dapat meningkatkan kedisiplinan dalam pengumpulan tugas mata kuliah Bahasa Indonesia. Kesimpulan bahwa penggunaan 
pembelajaran elektronik memiliki nilai positif bagi penggunanya yaitu guru, siswa, maupun dosen.

Sevima Edlink adalah sebuah aplikasi atau media pembelajaran elektronik yang dibuat oleh PT Sentra Vidya Utama (SEVIMA) sebuah perusahaan konsultan dan pengembang teknologi informasi yang didirikan pada tahun 2004. Saat ini memiliki lokasi kantor di Surabaya dan Jakarta dengan didukung oleh tenaga ahli muda yang kompeten, inovatif dan profesional yang berpengalaman di bidangnya. SEVIMA memiliki bidang fokus dalam sektor edukasi dan sektor pemerintahan.

Sevima Edlink merupakan salah satu media berbasis android bersifat mobile yang dikhususkan untuk dunia pendidikan guna membantu pendidik dalam proses pembelajaran. Beberapa manfaat Sevima Edlink bagi pendidik adalah untuk menghemat waktu, menjaga kelas tetap teratur dan meningkatkan komunikasi dengan pelajar atau peserta didik. Selain bermanfaat bagi pendidikan disini juga akan disebutkan manfaat aplikasi ini bagi peserta didik, seperti mempermudah dalam mengumpulkan tugas dengan singkat.

Media pembelajaran online Sevima Edlink bisa didapatkan di tautan https://app.edlink.id/ atau bisa didapatkan di playstore gawai android secara gratis. Tampilan depan media pembelajaran elektronik Sevima Edlink seperti dibawah ini:

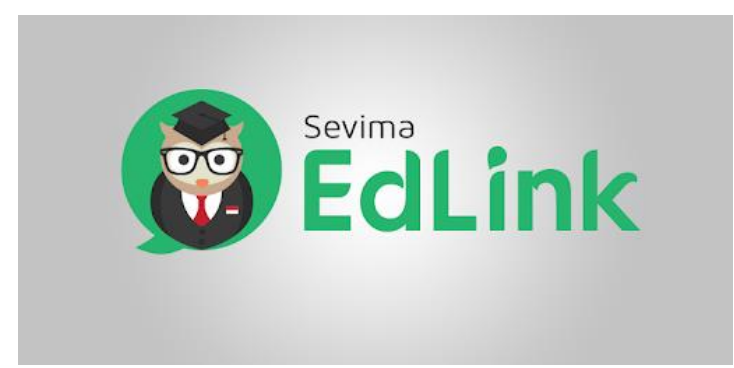

Gambar 1. Logo Sevima Edlink

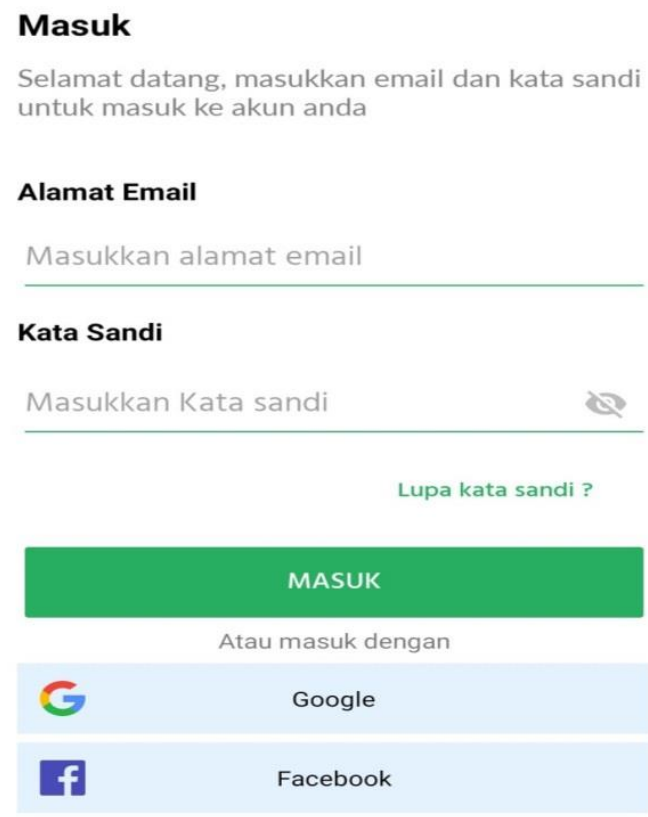

Gambar 2. Halaman Registrasi Sevima Edlink 
Saat pengguna sudah mengunduh media pembelajaran elektronik Sevima Edlink diharuskan untuk membuat sebuah akun memasukan sebuah pos-el yang aktif yang dimiliki oleh pengguna dan membuat kata sandi yang mudah diingat oleh pengguna, setelah itu nanti sistem mengirimkan sebuah kode untuk memverifikasi akun yang dibuat. Setelah sudah dikirimkan kode untuk verifikasi maka bisa ke tampilan utama dari Sevima Edlink. Ada beberapa fitur-fitur yang terdapat pada laman utama Sevima Edlink seperti dibawah ini.

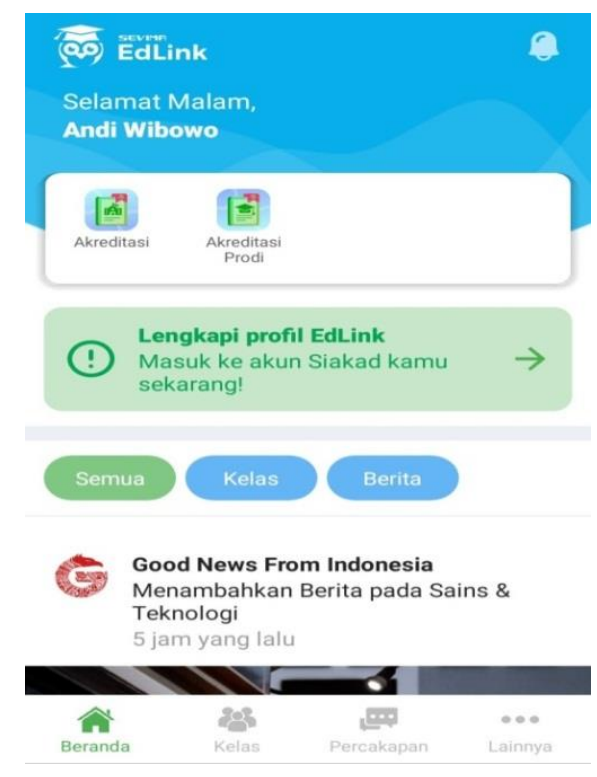

Gambar 3. Menu Sevima Edlink

Pada tampilan gambar diatas bisa terlihat ada fitur beranda, kelas, percakapan, akreditasi kampus, dan akreditasi prodi dan lainnya. Media pembelajaran online ini bisa digunakan untuk tingkat sekolah maupun perguruan tinggi, tetapi media pembelajaran online ini lebih banyak digunakan oleh perguruan tinggi. Media pembelajaran online ini bersifat gratis tidak dipungut biaya apapun.

Fitur detail yang terdapat pada media pembelajaran online yaitu:

\begin{tabular}{|l|l|}
\hline No & \multicolumn{1}{|c|}{ Fitur-Fitur } \\
\hline 1. & Video Konfrensi untuk pembelajaran jarak jauh \\
\hline 2. & Presensi siswa \\
\hline 3. & Jadwal Pelajaran atau Perkuliahan \\
\hline 4. & Pembuatan Kuis Interaktif \\
\hline 5. & Penanda/ Pengingat Jadwal Pelajaran \\
\hline 6. & Grup Kelas untuk berbagi materi dan pembelajaran \\
\hline 7. & $\begin{array}{l}\text { Penyerahan tugas jarak jauh oleh siswa maupun } \\
\text { mahasiswa }\end{array}$ \\
\hline
\end{tabular}




\begin{tabular}{|l|l}
\hline 8. & $\begin{array}{l}\text { Perekapan pembelajaran atau perkuliahan untuk } \\
\text { penilaian }\end{array}$ \\
\hline
\end{tabular}

Adanya beberapa fitur diatas, maka pengajar maupun siswa bisa melakukan pembelajaran jarak jauh dengan efisien dan mobile. Pada bagian fitur kelas, pengajar bisa membuat kelas sesuai dengan pelajarannya, pembuatan kelas tersebut bisa memilih kategori publik atau pribadi. Setelah pengajar sudah membuat kelasnya, pengajar bisa mengajak siswa ke dalam grup kelas tersebut dengan menggunakan sebuah kode verifikasi kelas. Pada grup kelas yang dibuat pengajar bisa memberikan materi pembelajaran berupa format dokumen, pdf, link video, maupun sebuah foto untuk dipelajari oleh siswa.

\section{METODE}

Penelitian menggunakan metode penelitian analisis kualitatif. Penelitian analisis kualitatif ini lebih memfokuskan pada pemahaman terhadap suatu objek, fenomena, dan kejadian. Penelitian kualitatif untuk mengumpulkan sebuah data tahap demi tahap yang dibuat secara naratif dan holistik. Penelitian ini tidak terikat dengan waktu dan tempat penelitian karena bisa dilakukan kapan saja, tetapi penelitian ini hanya memerlukan waktu dari bulan November tahun 2019 hingga awal Januari tahun 2020. Penelitian ini tempat penelitian bisa dilakukan di mana saja. Target dan sasarannya adalah siswa dan guru karena ingin memberitahukan bahwa media pembelajaran elektronik Sevima Edlink memiliki fitur-fitur yang bisa dimanfaatkan untuk belajar dan pengajaran bahasa Indonesia.

Penelitian ini menelaah dan analisis fitur-fitur yang terdapat pada media pembelajaran online Sevima Edlinkuntuk pengajaran dan belajar bahasa Indonesia. Penelitian ini menggunakan instrumen dari teori Sectionsdan Teori Chapple, setiap fitur yang terdapat pada media pembalajaran online Sevima Edlinkakan ditelaah dengan teori Sections dan Chapple. Penelitian ini menggunakan teknik pengumpulan data dokumen. Teknik dokumen lebih memfokuskan pada teks tertulis, gambar, ataupun foto pada subjek penelitian yang akan diteliti. Setiap fitur yang terdapat pada Sevima Edlink akan didokumentasikan melalui gambar atau foto lalu diberikan sebuah penjelasan dengan cara naratif. Teknik analisis data penelitian ini dengan cara peneliti menelaah fitur-fitur yang ada pada Sevima Edlink, kemudian peneliti menghubungkan fitur-fitur Sevima Edlink pada terori Sections dan Chapple. Setelah itu peneliti akan mengetahui bagaimana keseluruhan fitur-fitur yang terdapat pada Sevima Edlink.

\section{HASIL DAN PEMBAHASAN}

Bagian ini peneliti akan mengevaluasi teknologi maupun fitur-fitur yang terdapat pada Sevima Edlink dengan beracuan pada teori Sections dan Chaple. Berikut adalah evaluasinya.

\section{Student (Siswa)}

Pada media pembelajaran elektronik Sevima Edlink, media ini mempermudah siswa untuk mendapatkan sebuah materi dari pengajar sistem jarak jauh dan mempermudah siswa untuk memberkan tugas-tugas melalui fitur-fitur yang terdapat pada media Sevima Edlink.

\section{Ease Of use (Mudah Digunakan)}

Media pembelajaran elektronik Sevima Edlink dilihat dari penggunaannya sangat mudah digunakan, terlihat dari penjelasan diatas bahwa untuk mendapatkan sebuah media pembelajaran elektronik sekelas Sevima Edlink hanya tinggal mecari di laman intenet dan 
kemudian tinggal mengunduh media tersebut dan bisa juga diunduh lewat saluran Playstore berbasis android yang sudah tersedia secara gratis tanpa dipungut biaya apapun. Media ini dikatakan mudah dilihat juga dari pendaftaran akun media tersebut dengan hanya menggunakan pos-el pribadi dan kata sandi sesuai kemauan pengguna bisa lihat digambar 1.2. Penggunaan fitur yang lain pun juga mudah terlihat dari fitur yang disediakan, tinggal memilih data atau file yang akan diunggah dan langsung masuk ke kolom fitur yang digunakan.

\section{Cost (Biaya Penggunaan)}

Pada media ini tidak perlu mengeluarkan biaya penggunaan, karena tidak ada syarat untuk berlangganan menggunakan media Sevima Edlink, cukup tinggal mengunduh di laman internet maupun di laman plyastore android. Media ini sangat rekomendasi para pengajar untuk menggunakan media pembelajaran online dengan fitur-fitur yang sangat lengkap didalamnya. Untuk melihat fitur bisa dilihat di tabel fitur diatas.

\section{Teaching Function (Fungsi/Penggunaan Pengajaran)}

Media ini mempunyai fitur seperti gambar dibawah ini.

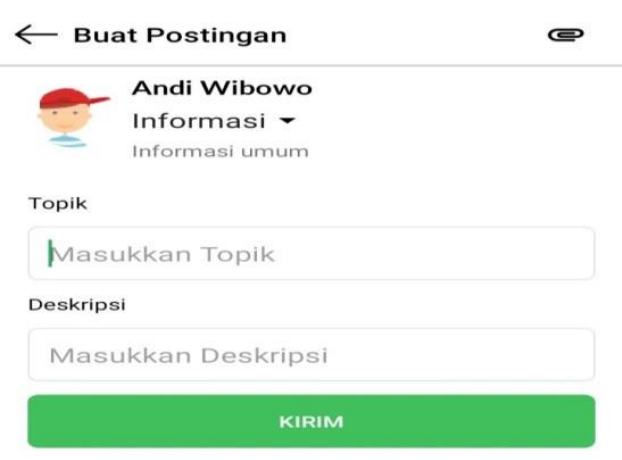

\section{Gambar 4. Fitur Sevima Edlink}

Gambar diatas secara jelas bahwa penggunaan media ini untuk pengajaran cukup mudah, tinggal mengetik topik apa yang akan dibahas, kemudian deskripsi sesuai dengan kemauan pengajar untuk materi yang diajarkan lalu tekan tombol kirim untuk mengirim materinya. Materinya untuk dimasukan dengan memilih tanda penjepit kertas yang terdapat pada pojok kanan atas, dibawah ini adalah tampilan tanda penjepit kertas. 


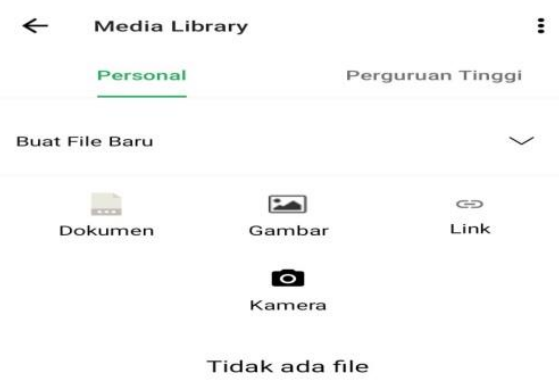

Gambar 5. Pilihan Dokumen Unggahan

Tampilan gambar 5 di atas pengajar bisa memilih format yang dibutuhkan maternya bisa berbentuk file dokumen, bisa berbentuk foto gambar, berbentuk tautan video ataupun berbentuk foto melalui kamera. Apabila dihubungkan dengan pembelajaran bahasa Indonesia, fitur ini sangat mendukung, karena pada pembelajaran bahasa Indonesia, pengajar bisa memberi pembelajaran keterampilan membaca dengan memberikan sebuah dokumen format file, dan bisa memberikan keterampilan menyimak pengajar bisa memberikan sebuah video atau rekaman video pengajar sendiri yang dibuatnya atau bisa memberikan tautan videonya. Apabila pembelajaran bahasa Indonesia mempelajari sebuah teks, maka bisa menggunakan fitur dokumen format file.

\section{Interaction (Teknologi yang Menyediakan Interaksi)}

Media pembelajaran elektronik Sevima Edlink ini mempunyai fitur untuk interaksi melalui percakapan, berikut adalah tampilannya.
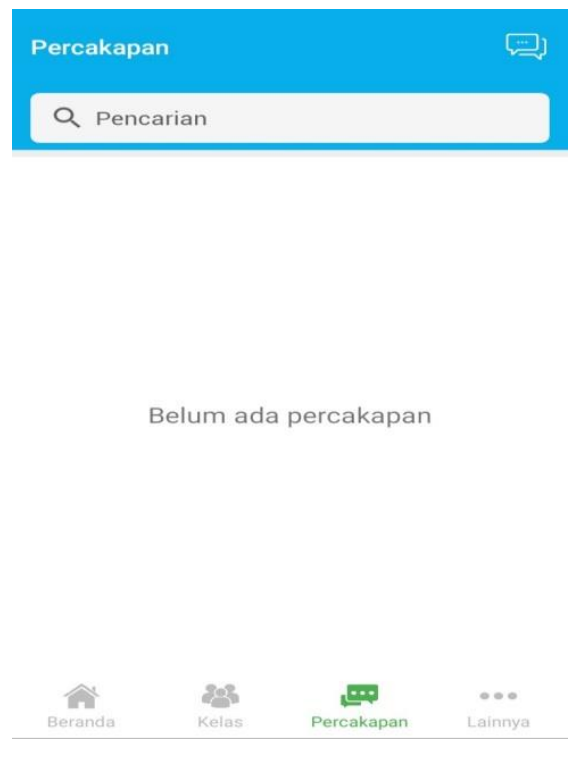

Gambar 6. Fitur Interaksi pada Sevima Edlink 
Pada tampilan gambar 3.3 terlihat bahwa teknologi atau fitur yang disediakan oleh Sevima Edlink untuk pengajar berinteraksi oleh siswa maupun mahasiswa. Interaksi yang dimaksud fitur media ini adalah berinteraksi dengan percakapan tulis pesan atau bisa berdiskusi peroraqng maupun kelompok tergantung kebutuhan pengajar untuk memberikan pengajaran. Apabila dihubungkan dengan pembelajaran bahasa Indonesia, fitur ini bisa dijadikan sebuah media diskusi siswa maupun mahasiswa yang dibuat oleh pengajar.

\section{Organisational (Masalah yang Ada Pada Lingkungan)}

Media ini apabila diterapkan di pembelajaran di sekolah MTs PKP Jakarta Islamic School pada pembelajaran bahasa Indonesia sudah bisa diterapkan, karena sekolah memberikan izin pada siswa untuk menggunakan gawai untuk media pembelajaran serta sekolah tersebut sudah mempunyai dua laboratorium komputer yang bagus untuk melaksanakan sebuah pembelajaran elektronik dengan media ini, jadi sejauh ini apabila media pembelajaran elektronik Sevima Edlink ini diterapkan tidak ada masalah.

\section{Networking (Saling Menghubungkan)}

Aspek ini apabila melihat media ini mempunyai sebuah fitur networking yang mencukupi, terlihat dari fitur kelas dengan digolongkan dua jenis yaitu publik dan pribadi, selain fitur itu ada juga fitur percakapan yang menambahkan bahwa media ini mempunyai networking yang bagus antara pengajar dan siswa.

\section{Security (Keamanan \& Privasi)}

Pada aspek ini media Sevima Edlink mempunyai kemanan ataupun privasi yang bagus, terlihat dari untuk menggunakan media ini membutuhkan pos-el maupun kata sandi yang dibuat oleh pengguna, jadi orang lain pun tidak bisa menggunakan sembarangan. Melihat fitur di dalamnya, terdapat fitur untuk jenis publik ataupun privasi. Bisa dikasatakan kemananan dan privasi pada media Sevima Edlink cukup bagus sesuai dengan kebutuhan pengguna.

\section{Evaluasi dengan Teori Chaple}

Penjelasan kali ini, peneliti ingin mengevaluasi media pembelajaran elektronik Sevima Edlink dengan menggunakan teori Chaple. Teori tersebut membagi tiga bagian untuk dijadikan sebuah acuan evaluasi, yang pertama yaitu Enchase Input, yang kedua adalah Interaction, dan yang ketiga adalah Linguistic Production.

Penjelasan pertama yaitu tentang Enchase Input, yang dimaksud adalah apakah dalam teknologi itu terdapat input bar yang membuat siswa mempelajarinya, dilihat media Sevima Edlink, media tersebut memiliki fitur yang memberikan siswa untuk memperlajarinya sendiri tanpa adanya bimbingan dari pengajar. Secara keseluruhan teknologi yang terdapat pada media Sevima Edlink mudah dipahami dan dipelajari dengan sendiri. Siswa pun bisa mempelajari materi yang disampaikan oleh pengajar.

Aspek ini apabila dihubungkan dengan pembelajaran bahasa Indonesia, contoh seorang pengajar memberikan sebuah materi teks prosedur, maka pengajar akan mengunggah materi bisa berbentuk dokumen ataupun bisa berbentuk sebuah tautan video. Materi pembelajaran teks prosedur yang berbentuk dokumen berisikan tentang penjelasan-penjelasan teks prosedur mengharuskan siswa membaca isi dokumen tersebut. Kedua pengajar bisa mengunggah tautan video tentang materi teks prosedur untuk memberikan contoh secara jelas materi yang diajarkan. Ketika materi tersebut sudah diunggah oleh pengajar, maka siswa bisa 
mengakses sendiri materi yang diunggah oleh pengajar. Siswa pun bisa berulang-ulang untuk membaca materi tersebut apabila siswa tidak bisa memahami materi tentang teks prosedur tersebut.

Penjelasan kedua yaitu Interaction, yang dimaksud adalah mampukah media tersebut memberikan ruang bagi guru untuk menjelaskan. Media Sevima Edlink ini memberikan fitur untuk memberikan pengajar untuk menjelaskan materi yang akan disampaikan yang terlihat dari gambar 3.1 dan gambar 3.3. Kedua fitur itu memberikan pembelajaran elektronik yang aktif melalui sistem jarak jauh.

Aspek ini apabila dihubungkan dengan pembelajaran bahasa Indonesia, contoh apabila pengajar memberikan sebuah materi tentang puisi, pengajar bisa menggunakan fitur percakapan yang terdapat pada gambar 3.3. Pengajar bisa menjelaskan materi puisi tersebut di kolom percakapan, kemudian selain menggunakan fitur percakapan, pengajar juga bisa menggunakan fitur video conference, fitur ini bisa didapatkan di kelas yang dibuat seperti gambar 3.1, di dalam fitur kelas itu, ada fitur video.

\section{SIMPULAN}

Hasil evaluasi untuk media Sevima Edlink ditelaah dengan menggunakan teori Sections dan Chaple, bahwa media Sevima Edlink ini sangat direkomendasikan untuk dijadikan sebuah media pembelajaran elektronik pada pembelajaran bahasa Indonesia, karena memiliki fitur-fitur yang mendukung pada kebutuhan-kebutuhan pembelajaran bahasa Indonesia. Media Sevima Edlink ini selain bisa memberikan materi, media tersebut juga bisa berinteraksi dengan jarak jauh melalui sebuah diskusi percakapan via tertulis maupun video. Media ini diharapkan terus dipromosikan di satuan pendidikan yang terandah hingga yang tertinggi agar akademisi maupun pelajar bisa mengetahui adanya keberadaan media Sevima Edlink ini.

Saran dari peneliti adalah untuk fitur yang sudah ada sementara bisa ditingkatkan lagi agar pembelajaran jarak jauh semakin nyaman dan media ini lebih baik bisa digunakan digunakan dari tingkat satuan pendidikan yang terendah tanpa ada kategori media yang sering digunakan oleh perguruan tinggi.

\section{DAFTAR PUSTAKA}

Al-fraihat, D., Joy, M., \& Sinclair, J. (2020). Computers in Human Behavior Evaluating Elearning systems success : An empirical study. Computers in Human Behavior, 102(March 2019), 67-86. https://doi.org/10.1016/j.chb.2019.08.004

Andi \& dkk (2020).Evaluasi Pembelajaran Berbasis Teknologi Informasi dan Komunikasi HUMANIS : Jurnal Pengabdian Kepada Masyarakat. 19, 1-5.

Eliando \& Purnomo. (2019). Rancang Bangun Aplikasi Hybrid Untuk Media Pembelajaran. STEM - Matana University Tower 125.

Ghufron, M. A. (2018). Revolusi industri 4.0: tantangan, peluang dan solusi bagi dunia pendidikan. 332-337.

Harun, I., \& Fauzan, M (2019). Penggunaan Teknologi Informasi dan Komunikasi dalam Pembelajaran oleh Guru Pendidikan Agama Islam 1(2), 88-99

Miftah, Indriani \&Hardianto (2019). Biology Teaching and Learning Penggunaan Media Android dalam Pembelajaran Sistem Gerak. 87-92.

Muhammad Abror Amanullah. (2020). Pengembangan Media Pembelajaran Flipbook 
Digital Guna Menunjang Proses Pembelajaran di Era Revolusi Industru 4.0 JDPP. 3844.

Prabandari, S. (2019). Mobile Learning Sebagai Media Komunikasi. Jurnal Lentera

Komunikasi: Politeknik LP3I Jakarta

Rika Mulyati Mustika Sari\&Nanang Priatna,. (2020).Model-Model pembelajaran di Era Revolusi Industri 4.0 Biormatika : 6(1), 107-115.

Satya, V. E. (2018). Strategi Indonesia Menghadapi Industri 4.0. Puslit BKD : 19-24

Supriadi, N., \& Widyastuti, R.(2019) Pengaruh Model Pembelajaran E-Learning Berbantuan

Media Pembelajaran Edmodo Terhadap Kemampuan Pemecahan Masalah Matematis

Peserta Didik. 3(1), 31-42

Syamsuar \& Reflianto (2018). Pendidikan dan Tantangan Pembelajaran Berbasis Teknologi Informasi di Era Revolusi Industri 4.0

Widarma, A. (2019). Grand Design Pengembangan Teknologi Informasi \& Komunikasi (TIK). 4(1), 105-110

Yazdi, M., D. J., \& Tadulako, U. (2012). E-Learning Sebagai Media Pembelajaran. 2(1), $143-152$.

Yusuf, A Muri. (2014). Metode Penelitian Kuantitatif, Kualitatif \& Penelitian Gabungan. Jakarta. Prenadamedia Group 